AFRICAN

\title{
The effectiveness of Confucius Institutes as a tool of China's soft power in South Africa
}

\author{
by Maddalena Procopio* \\ London School of Economics \\ London, United Kingdom
}

\begin{abstract}
The link between teaching Chinese as a foreign language and the role of China on the international stage has grown in importance since 2004 when the Confucius Institutes programme was launched. Despite the confusion that surrounds the categorisation of the relationship, Chinese circles increasingly consider the language institutes as a tool of soft power in "support of the rise of China". The paper analyses the meaning of "cultural" soft power and attempts to measure its effectiveness in support of China's foreign policy aims through the study of Confucius Institutes in South Africa. Based on fieldwork data, the paper unpacks the reality on the ground through a study of the process of attraction at the executive level as well as at the students' level. It concludes that Confucius Institutes, despite attempts by a number of Chinese actors to promote their presence and activities in South Africa, can only be partially effective tools of soft power. Focusing on the modalities, as opposed to the breadth, of the engagement provides a more accurate prediction of long-term outcomes. While the initiative's aim of exposing people to China, albeit briefly, is

* Maddalena is PhD Candidate in International Relations at the London School of Economics. Her research focuses on Kenyan responses to Chinese activities in the Trade, Healthcare and Education sectors, with emphasis on Kenyan agency. She is also Associate PhD with ANR EsCa where she is conducting research on Chinese soft power in Africa.
\end{abstract}


AFRICAN

EAST-ASIAN

AFFAIRS

efficiently fulfilled, the project's ultimate aim to support China's rise is more dependent on the content of the interaction experience than is currently accounted for.

\section{Introduction}

Since the late 1990s, the Teaching of Chinese as a Foreign Language (TCFL) has become an important tool of Chinese foreign policy, not merely to "popularise Chinese language and culture throughout the world", but mostly "to enhance the friendship and mutual understanding as well as the economic and cultural cooperation and exchanges between China and other countries around the world, and to elevate China's influence in the international community" (Ministry of Education of the People's Republic of China). From the 1980s onwards the economic development that led millions of Chinese out of poverty, together with the "Go Out" policies created in the late 1990s, made China look less alien in terms of business opportunities and more appealing in cultural terms. This stimulated increased demand for cultural exchanges, including language-driven ones (Chen, 2015).

The link between language and the role of China on the international stage became even stronger after 2004 when the project of Confucius Institutes ${ }^{1}$ (CIs) was launched by the Hanban (China National Office for Teaching Chinese as a Foreign Language) with the aim of "meeting the demands of foreign Chinese learners and contributing to the development of multiculturalism and the building of a harmonious world" (Chinese Language Council International, Hanban). Born in the aftermath of Hu Jintao's (President of the People's Republic of China between 2002 and 2012) "peaceful rise" policy promotion (since 2003), the government-funded institutes are well-suited to the Chinese government's efforts to promote, through language and other tools of soft power (such as the media), a self-tailored image of China vis-à-vis not only the one that had long been shaped by others, but also the one damaged by practices of Chinese migrants overseas, uncontrolled by the state. Debates have raged over the type of image promoted and the modalities of promotion, with some arguing that a propaganda-based approach is adopted. This 
criticism has only recently started to be grounded upon empirically based studies (Hartig 2010, 2012, 2014) as opposed to studies based on generalised definitions.

The question that this paper attempts to answer is the extent to which Confucius Institutes are effective tools of China's soft power. Ten years after their establishment it is still not clear whether they are fulfilling the initial foreign policy aims they were associated with, namely to spread language and culture overseas, support multiculturalism and a harmonious world and, through this, support China's rise. The analysis below takes into consideration the numerical indicators used to measure effectiveness and unpacks them in a qualitative fashion to explain the CIs' role and their success as tools of foreign policy. The paper first explores the link between teaching Chinese as a foreign language and the role of China on the international stage, including the birth of the Confucius Institutes' initiative and the foreign policy aims it was associated with. Then it elaborates in more detail on the link between Confucius Institutes and soft power, providing a brief overview of the Chinese understanding of this link and its evolution. It then discusses findings with particular reference to the case of South Africa. Despite the general nature of the argument, its articulation is based on an understanding of the subject through the specific lens of the case study. As a consequence, a number of propositions may not hold in other contexts. This is the reason why the paper emphasises the importance of context analysis.

The findings of the case study are based upon two field trips to South Africa between 2012 and 2014. Interviews were carried out with the executive, namely CI/CC managers (including the Chinese and local directors) and teachers, where possible. Although a limited number are cited in the text, interviews were conducted with at least one manager per $\mathrm{CI} / \mathrm{CC}$, and in most cases with more than one. The findings concerning students' perceptions are not based on systematic interviews but on information gathered through the executive. This is a limitation of the study that was dictated by logistical constraints. It could and should be overcome with further research.

The case study is not used as a means of making generalisations but as an 
AFRICAN

EAST-ASIAN

AFFAIRS

empirically grounded example upon which the argument is constructed, with an awareness that more such cases are needed to be able to draw generalised conclusions or comparisons. The expansion of CIs in Africa is often considered more peculiar than in other regions due to the absence of Chinese language centres prior to the establishment of CIs and due to the arguably enhanced power asymmetry between any given country and China. South Africa was selected as a potentially significant case due to its hosting the highest number of CIs on the continent. While the argument below attempts to downplay the importance of numerical indicators as opposed to a qualitative reading of the phenomenon, the presence of a higher number of CIs was deemed important as a first logical selection to be able to provide a more comprehensive picture.

\section{Language teaching and foreign policy}

In the 1950s and 1960s TCFL "started to serve China's foreign diplomacy and build up international relations, mainly working with socialist countries and the Third World" (Yang X., 2010:91). The first teachers sent abroad to teach the Chinese language left in 1952 and the first language textbook to be taught abroad was published in 1958 by Beijing University. In the meantime, in China, Tsinghua University was the first, in 1951, to start a language course to teach Chinese to foreigners (Zhao and Huang, 2010:130). The period from the 1950s through to the 1970 s was characterised by the promotion of revolutionary ideals at home and abroad and only limited openness towards the outside world. With Deng Xiaoping's (leader of the People's Republic of China from 1978 to 1992) economic reforms, which started in the late 1970s, China started focusing on domestic economic and industrial modernisation while slowly opening up. In the late 1970s and early 1980s the first significant numbers of foreigners started to study Chinese in China.

In 1987 the Hanban was established as an office affiliated with the Ministry of Education with the aim of "meeting the demands of foreign Chinese learners and contributing to the development of multiculturalism and the building of a harmonious world" (Chinese Language Council International, Hanban). The spectacular economic development witnessed throughout the 1980s within China 
increased its confidence not only domestically but also on the international stage. With the rise to power of Hu Jintao in the early 2000s, the new ideal of a harmonious society started shaping Chinese ideology domestically, and its foreign policy equivalent became the promotion of China's peaceful rise/development. In January 2006, Hu Jintao told the Central Foreign Affairs Leadership Group that the increase in China's international reputation and status "will have to be demonstrated in hard power as the economy, science and technology, and defence, as well as in soft power such as culture" (Li and Luo, 2013: 31). Along these lines, according to the Chinese Ministry of Education (2010):

"Teaching Chinese as a Foreign Language (TCFL) is an integral part of China's reform and opening up drive. To promote TCFL is of strategic significance to popularise the Chinese language and culture throughout the world, to enhance the friendship and mutual understanding as well as the economic and cultural cooperation and exchanges between China and other countries around the world, and to elevate China's influence in the international community".

The Confucius Institutes project, founded in 2004, originated and grew in this domestic and foreign policy context. Although CIs are referred to as non-profit public educational institutions (Chinese Language Council International, Hanban) they are governed by the Hanban, a body jointly run by 12 different ministries and commissions, which are, in turn, regulated by the State Council, an institution that is led by the Chinese Communist Party (CCP). The Hanban has overall control of an area of Chinese education that includes not only Confucius Institutes, but also policies and development plans concerning Chinese language learning overseas, the development of language teaching material, teachers' training and dispatch, and Chinese Language examinations. CIs currently constitute a great share of TCFL and are strictly linked to China's political agenda as part of China's objectives for national development. The Chinese Confucius Institutes Online website reports that by the end of 2013, more than 400 Confucius Institutes and more than 600 Confucius Classrooms had been established. This stunning expansion provides a fertile ground for questions concerning, in particular, the effectiveness of these institutes in their contribution to China's foreign policy aims. 
AFRICAN

EAST-ASIAN

AFFAIRS

In the case of Africa, King (2013) reports that "from 1954 up to 2003, there had already been some 150 teachers sent to teach Chinese in 15 African countries". He continues, stating that "even if there are in 2013 more teachers present in one year now than there were in total over a period of 50 years, the aspiration for them to play a crucial role in China's co-operation more generally was already present, but in a less structured way" (King, 2013: 47). The "structured way" he refers to was introduced in Sino-African relations - not only in education but more generally in all areas of co-operation, exchange and interaction - in 2000 with the first Forum on China-Africa Cooperation (FOCAC). The Forum institutionalised the foreign policies of China and African countries towards each other and guaranteed continuity of engagement in areas as diverse as education, healthcare, and security.

The first Confucius Institute in Africa was set up in 2005 at the University of

\begin{tabular}{|l|l|l|l|}
\hline $\begin{array}{l}\text { Table 1. Confucius Institutes and Confucius Classrooms aggregate } \\
\text { distribution }\end{array}$ & 2012 & 2013 & $2015^{*}$ \\
\hline & & & \\
\hline $\begin{array}{l}\text { North America } \\
\text { (USA and Canada) }\end{array}$ & 80 & 491 & 485 \\
\hline Europe & 106 & 298 & 302 \\
\hline Asia & 83 & 143 & 147 \\
\hline Oceania & 12 & 65 & 66 \\
\hline Africa & 22 & 45 & 48 \\
\hline $\begin{array}{l}\text { Latin America } \\
\text { Data gathered by the author between 2012 and 2015, based on the Confucius } \\
\text { Institutes official website }\end{array}$ \\
$*$ to the date the article was submitted, June 2015.
\end{tabular}




\section{AFRICAN \\ EAST-ASIAN \\ AFFAIRS \\ THE CHINA MONITOR}

Nairobi. The establishment and management of Confucius Institutes became part of FOCAC's triennial commitments under the section named "Cooperation in the field of development " together with other areas such as medical cooperation, environmental protection, and tourism, to name a few. Educational and cultural cooperation also included human resources development, science and technology transfer, cultural and people-to-people exchanges and cooperation, and exchanges between academia and think-tanks. Within Africa there are currently 30 (16 in 2012) countries that host Confucius Institutes. South Africa has set up one Confucius Classroom and four Confucius Institutes ${ }^{2}$, the highest number of institutes in one single country in Africa, followed by Kenya and Ethiopia with four institutes each, Tanzania with three, Egypt, Morocco and Nigeria with two institutes per country and twenty-three other countries with one institute each $^{3}$. The number continues to increase, although in Africa the total is still relatively small compared to the total number of CIs/CCs set up in North America (USA and Canada) or Europe, respectively 485 and 302 in 2015.

\section{Confucius Institutes and "cultural " soft power}

Despite the fact that language teaching has reportedly become a tool of foreign policy, the link between Confucius Institutes and soft power is not, for many, readily evident. Debates have raged - and still do - over the ultimate aims of this project. Arguments for and against the institutes range from describing them as language institutes with no particular political connotation to presenting them as instruments of propaganda. What is interesting to note is an apparent lack of coordinated understanding even within the decision making organs in China of what these institutes are, what "culture " is, what aspects of it should be promoted abroad and what other sources of power become intertwined with cultural promotion. Clarifying these elements is a necessary analytical step for the evaluation of effectiveness, inasmuch as effectiveness is related to objectives and objectives are related to the way the initiative is conceived.

\section{Understandings of the role of CIs}

As mentioned above, in $2006 \mathrm{Hu}$ Jintao highlighted that China's rise should be based on hard and soft power, such as culture (Li and Luo, 2013: 31). Five years later, Mrs 
AFRICAN

EAST-ASIAN

AFFAIRS

THE CHINA MONITOR

Xu Lin, the Director-General of Hanban and Chief Executive of the CI Headquarters, declared that not only did culture and soft power belong to two distinct spheres, but also that Confucius Institutes had nothing to do with soft power or politics. She stated that:

"The CI has nothing to do with soft power. The Chinese culture is still a weak culture. So we go international in fact just to increase real face-to-face communication between Chinese and foreign cultures. I am against the term soft power. The CI has nothing to do with soft power. Indeed we go international in order actively to reflect and refresh our culture rather than export it. The purpose for CIs to go international is to let more foreigners know more about China. The most important thing is that CIs provide a platform without any distance to increase face-to-face real communication between Chinese and foreign cultures. There is no ideological element in the CI; it is completely cultural. Therefore the CI can't be called a kind of Mao Zedong Institute; it has nothing to do with politics". (Xu Lin, 2011).

This statement raised a few questions, in particular as regards to what culture is, what aspects of it should be promoted and if it can be fully detached from politics. To add complexity to the Chinese understanding of the institutes, and the connection between culture and soft power, in 2014 Peking University launched a centre dedicated to soft power, to help the government spread Chinese culture and values abroad. The Minister of Culture, Cai Wu, stated at the launch that:

"cultural soft power is beginning to offer strong support for the rise of China. The country must enhance its cultural strength in order to dominate the global contest for soft power" (Ma, 2014).

The implication of this statement is not only that culture and soft power are strongly related to each other, but also that they are supporting China's international relations agenda. However, it remains unclear how this support is measured. In turn, if Confucius Institutes are acknowledged to be a tool of support for the government in spreading Chinese culture, then Minister Cai Wu's statement contradicts King's thinking that CIs "have altogether a more modest ambition than global competition 
AFRICAN

for influence with the West” (King, 2013: 178).

\section{The culture of CIs and the link to politics}

The emphasis on "cultural" soft power brings us back to the discussion over what culture is, the extent to which it can be detached from politics - which is what the "cultural" attribute to soft power seems to be distancing itself from - and what parts of it should be promoted. The culture the Chinese government seeks to promote overseas generally revolves around traditional artistic expressions (calligraphy, medicine, martial arts and so forth), exchanges and business (Lo and Pan, 2014:11). Confucius as an ambassador of Chinese language and culture is not used to teach about Confucianism; indeed, as Lo and Pan suggest, he is barely utilised to teach about the contemporary meanings associated with Confucius' teachings - only "ideals of harmony, peace, stability and orderliness" (2014: 11). It is mostly used as an emblem of literary excellence. Mrs Xu Lin in 2011 stated that:

"All over the world, if someone has any culture at all, they know that China had someone named "Confucius ". Thus, all over the world, Confucius is recognised as an educator, a thinker and a philosopher. Also, he was a philosopher over 2560 years ago. So if we call this the Confucius Institute, foreigners will all immediately know that this is a cultural brand of China. It's because it's called the Confucius Institute that it was like it was given wings to fly very fast because many people are fans of this name".

Leaving aside the assumption that Confucius is really that well known worldwide, it is important to emphasise that the decision to focus on a few specific elements of Confucianism and the failure of the institutes to expose students to the breadth and depth of traditional Chinese culture or contemporary creations, is an example of how culture is forced onto restricted and simplistic notions of identity. Some argue that this is due to the difficulty, even for Chinese students, of understanding such elaborate cultural expressions, but it is also possible to argue that a given culture is often a reflection of political dynamics, and simplifying it downplays the importance of politics. Notwithstanding this, it would be an exaggeration to argue that this limitation equates to propaganda, like many fear, but it is sensible to think of it as a 
AFRICAN

EAST-ASIAN

AFFAIRS

form of censorship. Yang suggests that:

"there appears to be little factual support for the accusation for improper influence over teaching and research of CIs. The CI headquarters in Beijing does not dictate the curricular design of a language or cultural program. The teaching materials provided by Beijing have been designed to facilitate pedagogical needs and are not intended for propaganda purposes. The headquarters cannot control the contents of lecture series or the design of a festival program". (Yang, R. 2010: 237238).

But Hartig points out that "normally CIs tend to stay on the safe side by not engaging too much with "sensitive " issues" (2014:57). This self-censorship, which involves both a limited portrayal of Confucius - a portrayal that avoids emphasising the negative attributes with which he was associated during Maoism - and a consensual avoidance of "sensitive" issues at the ground level, is based upon the invocation of traditional values that intend to "soften the social impact of economic development on the citizenry at large" (Guo, 2008:8), domestically and internationally. Culture and politics are then more intertwined than it is at times suggested and the fast-paced economic development seems to enhance their amalgamation.

\section{Other power sources}

The economy-oriented attraction China exercises leads to the argument that it is the asymmetry in power relations that underpins the attractive qualities Nye asserts are part and parcel of soft power. Following on from Huntington's sobering rejoinder that soft power is dependent upon hard power, culture and ideology "become attractive when they are seen as rooted in material success and influence" (1996:92). Only the increase of hard power produces enhanced self-confidence and the belief in one's own cultural superiority, which in turn triggers an increase in its attractiveness to other people (Huntington, 1996:92). As it is no exception to this, in order to implement its soft power strategy, China leans on its hard economic power, namely trade, investment and its very economic development model, to raise the interest that underpins the increasingly diffused use of cultural means. 
Especially in the African context the appeal towards China is more focused on China's contemporary development achievements and the material accoutrements this allows, vis-à-vis the industrialised North, for whom the appeal of the Chinese way of life is also largely based on a more romanticised depiction of Chinese culture and its historical artefacts, though also on a crass desire to understand and exploit its proverbial "one billion consumers ". However, in African contexts, the role played by Chinese culture in the sense of the arts seems to be minimal in exerting attraction. It can, though, be a complement to the main sources of soft power, in other words, economic assets. According to Lo and Pan this is problematic. They suggest that:

"if foreigners are attracted to learn Chinese language and culture for economic purposes, then any downturn in Chinese economic development would inevitably dampen its cultural attractiveness". (Lo and Pan, 2014: 15-16; Gil 2008; Barr 2011).

On top of this, the fact that beyond economic attraction, only simplistic and limited notions of cultural identity are shared with foreigners seems to reduce China's possibilities of having an impact in the long term.

\section{Measuring effectiveness}

Effectiveness is the degree to which something is successful in producing a desired result. The ultimate desired result of Chinese soft power is to offer strong support for the rise of China. Support for the rise of China comes from different directions, but winning hearts and minds (soft power) has become a significant one and the promotion of language and culture has increasingly been recognised as an aspect of soft power in Chinese circles. CIs, by being mandated to promote Chinese language and culture overseas, are expected to contribute to providing support for the rise of China. But how to measure whether the support provided is effective? While the breadth of Confucius Institutes' diffusion is widely understood and often considered an appropriate measure of China's success in exerting attraction, focusing on the depth of such diffusion is less common, despite the relative advantage that an understanding of how much of China is appreciated can produce in the long term and for policy purposes. 
AFRICAN

EAST-ASIAN

AFFAIRS

The breadth of CIs diffusion indicates that they have boomed in the US and Europe. It also indicates that within Africa, South Africa has the highest number and that they keep increasing worldwide. However, it does not provide satisfactory answers as to the logic behind the establishment or the negotiations between demand and supply sides, which seem fundamental elements in establishing whether and how, as tools of soft power, they contribute to China's rise. It is thus necessary to turn to a more qualitative approach to be able to answer these questions. King highlights that the quantification of targets, "the number game" puts China under great pressure to continue to increase the long- and short-term training awards, almost as if the mere numbers correspond to "development" (King, 2013:205-206). Moreover, as Lo and Pan point out:

"Hanban has failed to realise that the rapid expansion of overseas institutions that are monitored and regulated by an authoritarian political system [...] could raise suspicion and concern among foreign peoples, especially those academics who worry that CIs would interfere with academic autonomy and freedom”. (2014: 7)

In a way, it is possible to state that there is a clash of perceptions between the Chinese for whom high numbers mean success and foreigners for whom high numbers, in this context, can symbolize a frightening expansion and penetration.

In order to understand the outcomes of soft power - whether it is effective or not understanding the context is key in acknowledging what is attractive, which is the resources of attraction or the assets that produce attraction, and what can be done to appeal more, which is the behaviour of attraction (Nye, 2004:6). According to Nye, soft power resources effectively translate into "the behaviour of attraction that can influence others towards favourable outcomes" (2012:153) only when the recipients' context guarantees that the culture promoted is attractive, when political values are consistent at home and abroad and when foreign policies are seen as "legitimate and having moral authority" (2004:11). Nye suggests that "with soft power, what the target thinks is particularly important, and the targets matter as much as the agents"(2004:34). In other words, the attractiveness of soft power resources, namely 
cultural products and values, and China's domestic and international development discourses and performances, depends as much on how local agents perceive them as it does on Chinese agents (Nye, 2012: 153).

\section{The case of South Africa}

Nye's pre-requisites are analysed with reference to the case of South Africa so as to establish whether Chinese culture can be attractive to South Africans, whether Chinese political values are consistent domestically and abroad, and whether they translate into a foreign policy that is perceived as "legitimate and having moral authority". Following the analysis of pre-requisites, a study of the behaviour is presented to show how executive and student targets engage with CIs and if they impact on the fulfilment of CI aims.

\section{Prerequisites}

In order to understand what elements of Chinese culture can be attractive to South Africans, it is necessary to overview the structural and ideological elements upon which South Africa's cultural interests and divisions rest. One of a handful of middle income countries on the continent, the South African economy has diversified away from a sole reliance on resource extraction, and has developed a modest industrial base, a solid financial services sector and even a small IT sector. In social terms, there is a visible segment of society - that is generally of white and Indian (with some mixed race and black Africans) background, reflecting the racial hierarchies of privilege under apartheid. Their orientation has traditionally been towards Britain, Europe and the United States, reflecting the colonial heritage and the prevalence of English amongst this group. At the same time, the vast majority of South Africans are of black African origin and their cultural reference points are broad, ranging from traditional Zulu, Xhosa and Pedi/Sotho sources, to British and American culture - especially through African-American culture - which has also had an influence on music and ideas. This diversified and layered context presents an especially complex setting for the projection of Chinese soft power.

South Africans, especially in urban areas, have been exposed to Chinese culture 
AFRICAN

EAST-ASIAN

AFFAIRS

since the late $1800 \mathrm{~s}$ when the first migration waves from China to Southern Africa started (Harris, 2012), in contrast to most other African countries where the presence of Chinese migrants and investments only became visible in the past 20 years. With Africa's largest number of South African born Chinese, who belong to different communities, South Africa offers unique insights into the processes of integration, alienation, and influence on its fulfilment of foreign and economic needs (Yap, 1996; Park and Tu, 2010). While the diaspora has created important societal links with South Africans over decades, ranging from cultural to economic ones, the most recent migration wave, which started at the beginning of the $21^{\text {st }}$ century, has given rise to "divided views on what being "Chinese means" (Alden and Wu, 2014:27) and has impacted on both relations with locals and those within the diaspora. Economic aspects have become the most visible contemporary form of engagement, as opposed to cultural exchanges. The South African population holds both positive (Smith and Van der Westhuizen, 2013) and negative (Ethics Institute of South Africa, 2014) perceptions regarding the economic dimensions associated with China's engagement with the country, mostly depending upon the sector of involvement, as noted by senior economist Tony Twine (Campbell, 2010). As Chinese migrants increase and their activities diversify, cultural attractiveness becomes increasingly connected and associated with the activities these actors engage in.

Beyond cultural attractiveness, the other element that Nye suggests is crucial in determining whether soft power can "work" in any given context is the consistency of political values. China's political values emphasise the importance of creating a harmonious society, where respect for authority is deep-rooted in people's mentality and economic development is the key to success. These values translate into a foreign policy of (attempted) non-interference with a strong focus on enhancing economic foreign policy and diplomacy. On the other hand, South Africa, considered by many a pivot between Africa and the rest of the world, has a complex and fragmented national identity that is anchored to historical events and has an impact on domestic and foreign policies. While China's call for harmony and noninterference is well received by a country like South Africa with a strong negotiation 
preference vis-à-vis the use of force to solve conflicts, respect for human rights has become a fundamental element of the socio-political discourses and practices in South Africa and in the country's foreign policies, though it remains less problematized in China. As a consequence of this, China's current political values are appealing to South Africans to a certain extent only. Alden and Wu suggest that:

"there are elements of the South African experience - from its commitment to democracy and the diversity of its civil society to its own economic and political aspirations on the continent - that may suggest barriers to the deepening of ties beyond a certain point”. (2014:27)

In other words, bearing in mind Nye's above mentioned prerequisites for soft power to be effective, while China's political values are consistent at home and abroad, its foreign policies are not thoroughly perceived as legitimate or morally acceptable. As such the soft power exercised may be irrelevant in a context where the content of such policies is not for all equally attractive.

\section{Behaviours of engagement: targets and aims}

The interests that characterise the engagement between local and Chinese agents vary in their overlapping and complementarity. By breaking down the process of establishing and managing a $\mathrm{CI}$ it is possible to identify different types of behaviour that help to provide a basis for more accurate qualitative measurements. At the executive level (composed of $\mathrm{CI} / \mathrm{CC}$ Chinese and local directors, as well as managers) the engagement is characterised by persuasion from the Chinese side and by specific interests and concerns from the host institutions in setting up a CI. At the students' level, the engagement needs to be investigated more comprehensively through further research. Available findings, however, suggest that South African students are generally attracted to studying Chinese partly because of China's economic promises and partly because of a set of cultural attributes. CIs' aims, however, often do not take into consideration students' particular motivations and are rather more oriented towards a mass provision of language courses only partially supported by additional activities. 
AFRICAN

EAST-ASIAN

AFFAIRS

\section{Executive level}

Starting from the decision to establish a CI, the Confucius Institutes By-Laws state that there must be "a demand for learning the Chinese language and culture at the applicant's location" (Chinese Language Council International, Constitution and ByLaws). The Chinese Embassy officials in South Africa also state that the Confucius Institute "is requested by African universities" (Officer at Chinese Embassy in Pretoria, interview, August 2012). Yet managers at the institutes in South Africa assert that the request mostly comes from China, or from business people deeply involved with China, or even the Chinese Embassy. The demand side of the equation was, in no case, triggered by bottom-up requests from students or staff; it was, rather, generally an executive strategy (CI Manager 2, interview, August 2012) put forward by the institutions' decision-making organs. This was generally a consequence of preliminary propositions by Chinese agents, including at times, invitations for future CI managers to attend CI conferences in China in order to exchange information concerning the challenges and benefits of setting up and running an Institute (interviews with CI managers, 2012, 2014).

The initial persuasion (at times supported by payments whose logic resides beyond the boundaries of soft power) is accompanied by both concerns and interests from the host institution's executive. Concerns mainly relate to a perceived uncertainty over the institutes' independence from the Chinese government, which is sometimes identified as "problematic" due to its poor human rights record and its authoritarian style, and feared to have potentially negative impacts on academic freedom. These concerns have, at times, translated into heated debates within the potential host institutions as, according to a few CI managers, the presence of China challenged South African institutions' relations with other partners, and institutions face the challenge of justifying their relations not only with China but with any other partner countries. One CI manager reported that:

"as an institution we have not decided why we partner with America, why we partner with Zambia. We never had political issues in our partnerships. But with China... it raises questions especially around human rights issues. And that was a 


\section{AFRICAN \\ EAST-ASIAN \\ AFFAIRS \\ THE CHINA MONITOR}

thing that challenged the rest as well: why do we work with America? It made the institution think about big picture issues". (CI Manager 2, interview, August 2012)

Similar concerns about the limitations regarding topics that are considered sensitive by China, such as the "One China Policy" or "Falun Gong", have sparked protests and withdrawal from the project in a few institutions across the world in light of academic freedom. This is not the case in South Africa. Most South African institutes have reported that the proposal they submit at the beginning of the year must be approved by Hanban in terms of budget, but that there are no clashes as far as the activities are concerned, although they are aware that certain topics are better avoided as sensitive. In South Africa most institutes do not perceive the limitation on the content as a reason to not run the institute, but rather as an element of Chinese culture that does not necessarily have to clash with language teaching. As one interviewee put it, the institute would not work if there was a particular push over the subjects of teaching "and the Chinese are starting to see it" (CI Manager 6, interview, August 2012).

The pro-active and regulatory approach is not equal to affirming that CIs spread propaganda content across the university. It is not equal either to stating that if it were not for persuasion there would be no interest in setting up the institute, but it does add complexity to what is described as a linear demand-supply phenomenon.

Beyond the persuasive behaviour, there are aspects of the engagement with China that are attractive at the executive level. This includes the expansion of connections with Chinese institutions; monetary, textual and human resources' assistance to set up and run the institute; prizes; links with other partners, including the private sector, and so forth. According to CI managers, one of the advantages in setting up an institute is the fact that "there's a shared credibility for you as a SA institution to be hosting an institute when you go and speak to other Chinese partners". Setting up an institute is seen as a "cornerstone for mutual understanding and broadening connections on which a lot of other initiatives could be built". It is also about "creating a network of friendships in China [...], looking for collaboration and opportunities". It is believed, by some, that "if the government strategy brings us closer together, universities need to take that on board and think about ways that 
AFRICAN

EAST-ASIAN

AFFAIRS

meet own goals" (CI Manager 2, interview, August 2012). Other interests concern opening an avenue for students to get funded, or the necessity of training students in Mandarin so that local organisations could benefit in their trading activities with China (CI Manager 3, interview, August 2012). In addition, the competition between the Chinese and other foreign actors provides South African institutions with more opportunities. According to a manager:

"[w]e have more offers [...] With the Chinese offering scholarships, the Americans are coming as well because of the competition". (CI Manager 3, interview, August 2012).

Then there is the attraction of receiving financial, textual and human resource assistance from the Hanban to set up and run the institute. Institutes and classrooms in South Africa receive between 50 per cent and 80 per cent of the annual funds from the Hanban to run the CI/CC. The budget submitted to the Hanban includes activities carried out throughout the year, including trips to China by staff and students. In other words, it does not only involve purely didactic, but also public relations' assistance. Despite the fact that the Hanban's support to foreign institutions should mainly be provided for the first three to five years, the institutes in South Africa still seem to be heavily reliant on the Hanban even after the initial phase. This aspect has been identified as problematic, especially if understood in terms of the sustainable development of the project. According to an interviewee:

"local universities do not see the opportunity of teaching Chinese, they are only happy because they get the money. They do not work hard to train local teachers and set up funds to pay teachers". (CI Manager 2, interview, July 2014)

This is, however, slowly changing in South Africa, with a couple of institutions starting to provide significant funding for the development of Chinese language curricula, whose reliance on CIs is reduced to teacher provision. The quality of teaching and teachers is also part of the current debate. The Hanban provides, through Chinese partner institutions, a Chinese director and Chinese teachers, most of whom are volunteers, often not fully prepared to teach Chinese as a foreign language and thus causing quality assurance concerns (Siow, 2011; Ren, 2012). 
Despite the fact that the training of local teachers would be advisable, there is scepticism concerning the Hanban's interests in letting host institutions develop their own teachers' body. According to an interviewee:

"even if we train all the teachers, they [the Hanban] would still send the director and the volunteers. I do not think it will ever develop into something independent because it would undermine the diplomacy". (CI Manager 3, interview, July 2014)

In this context of Chinese financial and human resource pre-eminence, the bureaucratic and day-to-day encounters between local and Chinese agents shape, from the bottom, the effectiveness of the institutes in support of China's rise. The trust that is built through exposure to each other and interaction varies and with it varies the commitment to deep and prolonged relationships. This trust is undermined when the Chinese quantification of targets, (in other words, the more the better), clashes with local expectations and practices, less concerned about the numbers than about the content. A South African manager pointed out that:

"the Chinese say there are 100 students, but they count double. There are 50 in the first semester and the same 50 in the second semester". (CI Manager 3, interview, July 2014)

When Hanban reports that the number of students registered at Confucius Institutes worldwide in 2011 was 500,000 doubts arise as to whether the figures are meant to seriously represent students' enrolment or, rather, to exaggerate the power of attraction. Similarly, incongruences between locals' expectations and CIs' aims, generate fears and suspicion or, at the minimum, confusion at the host institution's executive level concerning the behaviour that is appropriate within the statemonitored CI's structure. These fears, and the suspicion and confusion that comes with them, however grounded or not, may translate into a "stumbling block in the development of China's cultural diplomacy" (Lo and Pan, 2014: 7).

\section{Students Attraction}

Measuring the effectiveness of CIs at the student level involves, as with the executive level, an analysis of both the sources and behaviour of attraction. With 
AFRICAN

EAST-ASIAN

AFFAIRS

THE CHINA MONITOR

students, even more than with the executive, although a quantitative approach is often deemed appropriate to evaluate the effectiveness of $\mathrm{CIs} / \mathrm{CCs}$, counting the number of students enrolled - especially if for the first time - is not a good indication of how effective the institutes are as tools of soft power. This is particularly so when the effectiveness relates to the support for China's rise. In fact, the (high) enrolment of students in Chinese language courses is not a guarantee of generalised positive perceptions towards China and, as a consequence, of support for the country's rise. Notwithstanding this, a quantitative measurement can be an indication of how effective the sources of soft power are, as an aggregate, in raising the appeal of starting to study Chinese language and culture. These sources range from the arts to business and from language to traditional medicine. Mostly diffused through the media, Chinese migrants, the internet and other globalised means, these sources of attraction are also utilised by the institutes at particular events to attract prospective students. But is the initial interest and curiosity in China, that which motivates students to embark on a language course, already a measure of success in supporting China's rise? Or is the positive outcome dependent on the type of experience they embark on? The argument is that, as with the executive, the content of the experience can be crucial in determining the success of the initiative.

To add complexity to this quantitative versus qualitative debate, the number of students per institute/classroom has not significantly increased in the past few years, while the number of institutes and classrooms set up in South Africa is increasing. In looking for an explanation it is interesting to look at the type of courses offered. The levels taught range from beginners to degree level, but especially in primary and secondary schools the courses offered are mainly introductory and do not provide a developed curriculum after the initial introductory level. At the same time, the degree levels start from beginners so that students in secondary schools who wish to continue their studies do not necessarily see an appealing opportunity at the university level to continue their learning process (CI Manager 2, interview, July 2014). In the words of a South African manager:

"We can't stick to have beginners beginners beginners. We need more first, second, third year. Students should progress. But they [the Chinese] don't get it. 


\section{AFRICAN \\ EAST-ASIAN \\ AFFAIRS \\ THE CHINA MONITOR}

They want to have Chinese in more schools rather than deepening it down".

Manager 2, interview, July 2014)

This focus on the breadth rather than the depth of diffusion could be the result of decreased interest among students, but also the cause of such decreased interest. It can also be an aim in its own terms, as in the desire to expose the highest number of students to Chinese language and culture with the belief that even a brief exposure can produce positive results for the provision of support for China's rise. This as opposed to a deeper exposure that presumably provides more understanding (though maybe unnecessary for the purposes of supporting China's rise through the attenuation of negative perceptions) but where the students' interest is more difficult to maintain.

The focus on the quantity of enrolled students as an indication of effectiveness over the depth and quality shows its shortcomings also in relation to the quality of texts and teachers. The textbooks used are problematic mainly for their intellectual simplicity vis-à-vis language simplicity:

"the domestic Chinese scenes portrayed in the texts are alien to foreign readers, the materials go beyond their language mastery or acquisition abilities and the rote memorisation they require is too boring to arouse readers' interest (Confucius Institute Headquarters 2011)”. (Lo and Pan, 2014: 10)

These are, however, problems that do not only pertain to Confucius Institutes, but also to independent language centres as the books utilised to teach the language are often the same. This shortcoming can be addressed by integrating the language learning with cultural activities aimed at broadening the students' experience and understanding of China. In most institutions in South Africa these extra activities are part of yearly programmes. However, they are often one-off recreational events rather than scheduled as part of the academic disciplines. As for the teachers, the shortage of experienced teachers is a problem that is solved by sending volunteers abroad after they have received limited training that, in turn, causes quality assurance concerns, particularly linked to their inability to "develop or tailor teaching and learning resources and pedagogies effectively to meet the interests and 
AFRICAN

EAST-ASIAN

AFFAIRS

abilities of local students" (Lo and Pan, 2014: 10; Confucius Institutes Headquarters, 2011; Siow, 2011). These negative attributes of textual and human resources seem to create conflicts between the tools used to project soft power and the intended outcomes by providing an image of China that can only have limited appeal, especially in the long run.

The last aspect to consider when analysing the effectiveness of CIs at the student level is the modalities of attraction through the promise and provision of scholarships. There are a number of initiatives put in place at the global level to guarantee students experience China first hand. Within the context of CIs these initiatives include the Chinese Bridge competition, summer camps, CI scholarship programmes, the annual CI conference and other specific scholarships for targeted groups, for instance singers. Payments, such as the provision of scholarships and the funding of summer camps, seem to be appealing to students, especially in contexts where the economic asymmetry between China and the local context is significant. Scholarships are often provided at the beginning of a students' engagement with the CI and are aimed at providing students with a deeper understanding of China. Despite these efforts, interviews with CI managers suggest that unless the course is taken for a full university degree - in South Africa only provided by one tertiary institution through the CI - only a small portion of students continue in years beyond the first. Student rates drop significantly between the first and subsequent years.

On the whole it seems that CIs' objectives vis-à-vis the students revolve around exposing the highest number to Chinese language and culture, not only through the courses at foreign institutions but also through visits to China. By providing a platform to experience China the institutes do allow students to broaden their (pre) conceptions about the country even when the limited time of study does not allow for a deeper understanding. However, more empirical research is needed to provide a picture of students' experiences in South Africa and China so as to unpack how their expectations are met. This is crucial in evaluating how their initial interest towards China, i.e. the motivation to embark on a Chinese language course, is maintained and grows to the point of benefiting China's soft power aims. 


\section{Conclusion}

China is using a combination of hard and soft power in its foreign policy worldwide, including Africa. The domination of China's economic diplomacy in Africa has resulted in heated debates within and outside of African contexts as to the impact China would have in the social sphere. By observing their own transformation, Chinese leaders increasingly realised the importance of accounting for people's perceptions and reactions and started emphasising people-centred approaches. The Chinese language, often a tool of alienation from foreign populations due to its difficulty, has increasingly become a tool of foreign policy, a symbol of opening up. With the establishment of Confucius Institutes in 2004, language as a tool has become all the more important in acting as a medium to present a weighted image of China aimed, according to the Chinese, at counterbalancing the negative one produced by biased Western media, as well as Chinese migrants overseas. Critics have quickly jumped to portray the state-led educational centres as cradles for propaganda diffusion, accusing them of indoctrinating students. While these critiques have often overestimated the role of CIs, there has been little emphasis on the research front on providing accurate studies that move away from generalisations and take into consideration the loci of implementation.

Drawing on the findings of the South African case, it is argued that Confucius Institutes are only partially effective as a tool providing support for China's rise. While they are well able to attract institutions and students to respectively set up CIs and enrol, the types of behaviour involved vis-à-vis both the executive and the students can, at times, undermine the efforts. At the same time, the lack of proper evaluation mechanisms seems to suggest that the emphasis is not on how satisfactory and effective the educational experience is, but merely on providing such educational experience, as if the mere provision were sufficient to fulfil the project's aims. In particular, in relation to the executive, the confusion and suspicion over the bureaucratic system to which CIs are subjected and are part of, and the awareness that there exist norms of conduct when it comes to teaching content and practices, seems to translate into a nuanced trust as opposed to a complete trust, towards the Chinese management that could, in turn, act as an obstacle to further developments. 
AFRICAN

EAST-ASIAN

AFFAIRS

In the case of students, the objective of exposing high numbers of students to language and culture is a strategy that can prove effective in terms of allowing students to broaden their knowledge and understanding of China, and in turn expressing positive, or at the minimum less biased, opinions about China. However, whether this is a good strategy to fulfil the objective of making CIs an effective tool supporting China's rise remains to be seen as the students that are briefly exposed to China may be positively affected, but not to the extent of advocating for it in their future personal and professional lives.

As a consequence, while the initiative's aim of exposing people to China, albeit briefly, is capably fulfilled, the project's ultimate aim of supporting China's rise may be more dependent on the type of interaction experience than is currently accounted for.

\section{Endnotes}

1. While this paper mainly utilises "Confucius Institutes", the concept generally also represents Confucius Classrooms, meant as a sub-category of CIs.

2. One of the four that was originally set up at Tshwane University was later shut down and a new one was set up at Durban University of Technology.

3. Burundi, Benin, Botswana, Republic of Congo, Cameroon, Eritrea, Ghana, Comoros, Liberia, Madagascar, Mali, Malawi, Mozambique, Namibia, Rwanda, Seychelles, Sudan, Sierra Leone, Senegal, Togo, Tunisia, Zambia, Zimbabwe.

4. Although the website is only partially reliable, it is the only official source of information regarding the diffusion of CIs/CCs. Its partial reliability is due to the lack of precision in maintaining the list of CIs/CCs up to date as well as in providing overall numbers per region that are not always matched by the number of CIs/CCs per country. The Confucius Institutes' official website is available at: < http://english.hanban.org/node_10971.htm> 
AFRICAN

\section{Bibliography}

Alden, C. and Wu, Y., 2014. South Africa and China: The Making of a Partnership. South African Institute of International Affairs, Occasional Paper 199.

Barr, M. 2011. Who's Afraid of China? The Challenge of Chinese Soft Power. New York: Zed Books.

Bell, D. 2008. China's New Confucianism: politics and every day life in a changing society. Princeton: Princeton University Press.

Campbell, K. 2010. Some challenges ahead as SA's new 'partnership' with China takes shape. Engineering News, [Online]. Available: http:// www.engineeringnews.co.za/article/some-challenges-ahead-as-sas-newpartnership-with-china-takes-shape-2010-11-05

Chen, Z., 2015. Chen Zhili: a successful example of international Chinese language promotion and Chinese-foreign cultural exchanges - to the 10th anniversary of the Confucius Institute. Renmin Daily [Online] Available: http:// english.hanban.org/article/2015-02/05/content_573650.htm

Chinese Language Council International. 2011. Constitution and By-Laws of the Confucius Institutes [Online]. Available: http://english.hanban.org/ node_7880.htm

Confucius Institute Headquarters. 2011. Interview with Mrs Xu Lin [Online]. Available: http://www.hanban.edu.cn/news/article/2011-08/17/ content 290204.htm

Confucius Institute Headquarters. 2011. 2011 European Confucius Institutes Working Symposium Reference Materials. Beijing: Confucius Institutes Headquarters.

Confucius Institutes Online. 2014. [Online]. Available: http://www.chinesecio.com/ Cornelissen, S. 2010. The China Monitor: Let a Thousand Flowers Blossom, Issue 47. The Centre for Chinese Studies: Stellenbosch University. 
AFRICAN

EAST-ASIAN

AFFAIRS

Dietz, T., Havnevik, K., Kaag, M. and Oestigaard, T. (eds.). 2011. African Engagements: Africa Negotiating an Emerging Multipolar World. LeidenBoston: Brill.

Ding, S. 2008. The Dragon's Hidden Wings: How China Rises with Its Soft Power. New York: Lexington Books.

Ethics Institute of South Africa, 2014. Africans' Perception of Chinese Business in Africa: A Survey. Pretoria: Ethics Institute of South Africa [Online]. Available: http://www.ethicsa.org/phocadownloadpap/Research_Reports/ AfricanPerceptionSurveyChineseBusinessWEBSITEVERSION.pdf

Gadzala, A., and Hanusch, M. 2010. African Perspectives on China in Africa: Gauging popular perceptions and their economic and political determinants. Afrobarometer Working Paper 117. Legon-Accra: Afrobarometer.

Gil, J. 2008. The Promotion of Chinese Language Learning and China's Soft Power. Asian Social Science, 4(4).

Guo, X. 2008. Repackaging Confucius: PRC Public Diplomacy and the Rise of Soft Power. Asia Papers Series, Stockholm: Institute for Security and Development Policy.

Harris, K. 2012. The Chinese in South Africa: Five Centuries, Five Trajectories, in C.B Tan, (ed). Routledge Handbook of the Chinese Diaspora. Oxon: Routledge.

Hartig, F. 2010. Soft Power Push or Conspiracy: A Case Study of Confucius Institutes in Germany, Asian Studies Association of Australia, 18th Biennial Conference. Adelaide, Australia: 5-8 July 2010.

Hartig, F. 2012. Confucius Institutes and the Rise of China. Journal of Chinese Political Science, 17 (1): 53-76.

Hartig, F. 2014. The Globalization of Chinese Soft Power: Confucius Institutes in South Africa. CPD Perspectives on Public Diplomacy: Confucius Institutes and the Globalization of China's Soft Power. Los Angeles: Figueroa Press: 47-65. 
AFRICAN

Huang, Y., and Yang, D. 2002. Bureaucratic Capacity and State-Society Relations in China. Journal of Chinese Political Science, 7(1-2): 19-46.

Huntington, S. 1996. The Clash of Civilizations and the Remaking of World Order. Old Tappan: Touchstone Books.

King, K. 2013. China's Aid and Soft Power in Africa: The Case of Education and Training. Woodbridge, UK and Rochester, NY: James Currey.

Li, B. and Luo, J. 2013. Dissecting soft power and Sino-Africa relations in education and exchanges cooperation, in Li, A. and April, F.Y. (eds.). Forum on China Africa Cooperation: The Politics of Human Resource Development. Pretoria: Africa Institute of South Africa.

Lo, J.T. and Pan, S. 2014. Confucius Institutes and China's soft power: practices and paradoxes. Compare: A Journal of Comparative and International Education.

Ministry of Education of the People's Republic of China. 2010. A Brief Introduction of Teaching Chinese as a Foreign Language (TCFL) of China. Chinese Government, July.

Ma, X. (ed.). 2014. New center to strengthen China's soft power. Xinhua via People Daily [Online] Available: http://english.peopledaily.com.cn/n/2014/0929/c90782 -8789744.html.

Nye, J. 2004. Soft Power: The Means to Success in World Politics. New York: Public Affairs.

Nye, J. 2008. Public Diplomacy and Soft Power. Annals of the American Academy of Political and Social Science, 616(1): 94-109.

Nye, J. 2012. China and Soft Power. South African Journal of International Affairs, 19(2): 151-155.

Paradise, J.F. 2009. China and International Harmony: The Role of Confucius Institutes in Bolstering Beijing's Soft Power. Asian Survey, 49(4): 647-669.

Park, Y.J. and Tu T.H. 2010. Introduction: Chinese in Africa. African and Asian 
AFRICAN

EAST-ASIAN

AFFAIRS

Studies, 9:207-212.

Ren, Z. 2012. The Confucius Institutes and China's Soft Power. IDE Discussion Papers 330. Chiba: IDE, Japan External Trade Organization [Online]. Available: http://www.ide.go.jp/English/Publish/Download/Dp/330.html

Siow, M.W. 2011. China's Confucius Institutes: Crossing the River by Feeling the Stones. Asia Pacific Bulletin, 91.

Smith, K. and Van der Westhuizen, J. 2013. What South African citizens think of foreign policy. Business Day Live [Online]. Available: http://www.bdlive.co.za/ opinion/2013/07/19/what-south-africas-citizens-think-of-foreign-policy

Starr, D. 2009. Chinese Language Education in Europe: The Confucius Institutes. European Journal of Education, 44(1): 65-82.

Yang, R. 2010. Soft Power and Higher Education: an examination of China's Confucius Institutes. Globalization, Societies and Education, 8(2): 235-245.

Yap, M., and Leong Man, D. 1996. Colour, Confusion and Concessions: History of the Chinese in South Africa. Hong Kong: Hong Kong University Press.

Wu, Z. 2012. Lay down Development Plan and Cultivate Local Teaching ForceMdm. Xu Lin, Director-General of Hanban, Provides Insights into the Sustainable Development of Confucius Institutes [Online]. Available: http:// www.chinese.cn/hanban_en/article/2012-08/17/content_455435.htm

Xu, L. 2011. Interview with Hanban Director Xu Lin on Civilization Tour. CCTV-4, 25 July 2011. Available: http://www.hanban.org/news/article/2011-08/17/ content_290204.htm

Zhao, H. and Huang, J. 2010. China's policy of Chinese as a foreign language and the use of overseas Confucius Institutes. Education Research Policy Practice, 9 (2): 127-142.

Zhao, S. 2009. The Prospect of China's Soft Power. How Sustainable?, in: Li, M. (ed.). Soft Power: China's Emerging Strategy in International Politics. Lanham, MD: Lexington Books. 247-266. 